\title{
Thoracic Cancer TNM Finding v8
}

National Cancer Institute

\section{Source}

National Cancer Institute. Thoracic Cancer TNM Finding v8. NCI Thesaurus. Code C136292.

A finding about one or more characteristics of thoracic cancer, following the rules of the TNM AJCC v8 classification system. It refers to thymic tumors, lung carcinoma, and malignant pleural mesothelioma. 